\title{
EVALUATION OF INTRA-ARTICULAR THIO-TEPA IN RHEUMATOID ARTHRITIS*
}

\author{
BY \\ J. ZUCKNER, J. UDDIN, R. H. RAMSEY, G. E. GANTNER JR., A. M. AHERN, \\ AND R. W. DORNER. \\ St. Louis University School of Medicine, St. Louis, Missouri
}

The potential action of cytotoxic agents such as alkylating drugs and antimetabolites on the immune response and inflammatory process has suggested their trial in the treatment of rheumatic diseases. Nitrogen mustard was tried initially both by intravenous and intra-articular injection in the therapy of rheumatoid arthritis and gave variable responses (Jiménez Díaz, 1951; Jiménez Díaz, Lopéz García, Merchante, and Perianes, 1951; Shutkin, 1951; Phillips, Phillips, and Caraway, 1952; Cohen, Rose, and Cooper, 1953; Scherbel, 1957; Scherbel, Schuchter, and Weyman, 1957; Scherbel, Mackenzie, and Atdjian, 1963). Scherbel and others (1957) noted a rapid and prolonged decrease in joint swelling after the intra-articular injection of nitrogen mustard in patients with rheumatoid arthritis, but not a corresponding satisfactory relief of pain. $\mathrm{He}$, therefore, combined steroids with nitrogen mustard for intra-articular injection and obtained more beneficial results. When a purine antagonist, 6-mercaptopurine, was administered to patients with systemic lupus erythematosus the responses were equivocal (Lee, Meiselas, Zingale, and Richman (1961). The development of adjuvant-induced arthritis in rats has been successfully inhibited by 6-mercaptopurine (Kalliomäki, Saarimaa, and Toivanen, 1964). Methotrexate has been used experimentally in psoriatic arthritis (O'Brien, Van Scott, Black, Eisen, and Bunim, 1962; Black, O'Brien, Van Scott, Auerbach, Eisen, and Bunim, 1964). Recently, thio-tepa (N, $\mathrm{N}^{\mathrm{I}}, \mathrm{N}^{2}$ triethylenethiophosphoramide) has been reported to give satisfactory improvement after intra-articular administration to patients with rheumatoid arthritis (Flatt, 1962; Gross, 1963; Pace, Kantor, and McEwen, 1964). Some of the latter results are difficult to interpret because thio-tepa was, in many instances, combined with steroids or local anaesthetics for intra-articular injection.
Rheumatoid arthritis is a disease in whichin rheumatoid factor(s), an abnormal antibody(s) or antibody-like substance(s), is frequently present: Alkylating agents interfere with antibody production 00 and, therefore, could inhibit the possible immuneo reaction and inflammatory changes characteristic of rheumatoid arthritis. It seemed appropriate to 3 study this possibility in more detail.

Thio-tepa, an alkylating agent, was selected for? study because it can be placed in solution at a $p \mathrm{H}_{\vec{c}}$ which is not irritating to the tissues and, consequently, can be given by all parenteral routes. The present investigation describes our results afere intra-articular injection of thio-tepa into the knees joint of nineteen patients with rheumatoid arthritis.

\section{Procedure}

Thio-tepa* was supplied for this investigation in liquido form in a dose of $10 \mathrm{mg}$./ $\mathrm{ml}$. or $15 \mathrm{mg}$. per vial. It waso freshly diluted for each injection with sterile water $4.5 \mathrm{ml}$. for each $15 \mathrm{mg}$. thio-tepa. When doses of $60 \mathrm{mg}$. were injected, the thio-tepa was diluted in a $1: 10^{\circ}$ ratio with water so that a total volume of $12 \mathrm{ml}$. was injected.

The study was performed as a double-blind tria? utilizing saline injections as a control either in the same knee at different times or in the opposite knee at the sames time. There were 41 injections of thio-tepa in quantities $>$ ranging from $7 \cdot 5$ to $60 \mathrm{mg}$. (Table I, opposite). About? three-quarters of the injections were $15 \mathrm{mg}$. or greater Seven injections of $60 \mathrm{mg}$. were given to six patients. Theo maximum number of injections to any one patient was eight, totalling $172.5 \mathrm{mg}$. thio-tepa administered over a period of 10 months. 24 joints were injected. Seven ${ }^{\omega}$ of the articulations were also injected with hydrocortisone acetate in doses of $25-50 \mathrm{mg}$. for comparison.

* Supplied by Lederle Laboratories Division of Americant Cyanamid Company. 
TABLE I

NUMBER OF INJECTIONS

\begin{tabular}{c|c}
\hline Dose (mg.) & $\begin{array}{c}\text { No. of } \\
\text { Injections }\end{array}$ \\
\hline $7 \cdot 5$ & 10 \\
$15 \cdot 0$ & 13 \\
$30 \cdot 0$ & 10 \\
$45 \cdot 0$ & 1 \\
$60 \cdot 0$ & 7 \\
\hline
\end{tabular}

Most patients had moderate to severe disease according to the criteria of the American Rheumatism Association (Steinbrocker, Traeger, and Batterman, 1949). The degree of synovitis in the injected joints was graded as 1 or $2+$ in all but one joint; $2+$ synovitis was present in two-thirds of the joints. All but three patients were females. Most were over the age of 50.

The interval between injections was determined by several factors:

(1) The patient's response;

(2) The appearance of toxic manifestations, particularly haematological alterations;

(3) The size of the dose injected;

(4) The desirability of evaluation of possible delayed effects.

Because of this last factor a period of observation of at least 3 weeks was allowed after 40 per cent. of the injections. If injections of the smaller dose were followed by no improvement or by signs of worsening, a further injection was usually given at the next visit if there was no evidence of toxicity.

Patients were examined once weekly for the most part. Subjective improvement with regard to pain and stiffness and objective improvement with respect to range of motion, swelling, capsular thickening, tenderness, heat and amount of synovial fluid in treated joints were recorded. Improvement was graded as poor, fair, good, or excellent.

Routine surgical preparation was used before each injection. In most instances, ethyl chloride was sprayed over the site of injection for local anaesthesia. If fluid was to be aspirated, 18-20 gauge needles were used; for thio-tepa injection only, 22 or 24 gauge needles were satisfactory.

As much of the synovial fluid as possible was aspirated before instilling medication. For study purposes, aspiration of fluid only was performed in some instances without administering thio-tepa. After initial cell counts, synovial fluids were frozen until just before analysis. These were then centrifuged until microscopical examination no longer revealed the presence of leucocytes in the supernatant fluid. A portion of each of the cell-free synovial fluids was then directly used for the determination of its relative viscosity in an Ostwald type viscometer at $37^{\circ} \mathrm{C}$. (Schachman, 1957). The remainder was subjected to ultrasonic vibrations (Dorner, Gantner, Uddin, and Zuckner, 1965) and the sonified samples were used for all subsequent tests. These were:

(1) Paper electrophoresis by the method of Sandson and Hamerman (1958) using a Spinco Model R apparatus and a Spinco Analytrol;
(2) Latex test (Singer and Plotz, 1956) to assess the concentration of rheumatoid factor;

(3) Enzyme levels of beta-glucuronidase (Jacox and Feldmahn, 1955) and acid phosphatase (Powell and Smith, 1954).

Altogether 37 synovial fluids obtained from eight patients were analysed. Usually synovial fluids were studied before and 1 week after thio-tepa injections. One patient had fluids evaluated at eleven different intervals between 1 and 6 weeks after the administration of 15,30 , or $60 \mathrm{mg}$. thio-tepa.

Haematological studies were performed at most visits. These included a CBC, erythrocyte sedimentation rate, and platelet count. A latex test in the serum was also performed regularly.

\section{Results}

There was no significant difference in local improvement following thio-tepa or control injections on the basis of both immediate and delayed effects. Results are shown in Table II. Subjective improvement was considered satisfactory (good or excellent improvement) after twenty of 41 injections, but similar objective improvement was not apparent; in only three instances did objective and subjective improvement correlate. Control injections gave equally good results in most instances. After one injection, thio-tepa was considered better than the control, and in three others only questionable slightly better. The amount of thio-tep administered had no apparent effect on responses as nine patients were tried on varying dosages up to $60 \mathrm{mg}$. Of the seven injections of $60 \mathrm{mg}$., six resulted in a poor response both subjectively and objectively. One patient had excellent subjective improvement after a $60 \mathrm{mg}$. injection, but only fair benefit objectively, and a control injection in this last individual was also accompanied by an excellent subjective response. In four patients, local administration of hydrocortisone acetate gave superior results to thio-tepa; in two, hydrocortisone acetate was possibly slightly better; in another thio-tepa was questionably slightly superior.

TABLE II

RESULTS WITH INTRA-ARTICULAR INJECTIONS OF THIO-TEPA

\begin{tabular}{|c|c|c|c|c|}
\hline \multicolumn{3}{|c|}{ Improvement } & \multirow{2}{*}{$\begin{array}{c}\text { Subjective } \\
19 \\
2 \\
19 \\
1\end{array}$} & \multirow{2}{*}{$\begin{array}{c}\text { Objective } \\
31 \\
7 \\
3 \\
0\end{array}$} \\
\hline $\begin{array}{l}\text { Poor } \quad . \\
\text { Fair } \quad \ldots \\
\text { Good } \\
\text { Excellent }\end{array}$ & $\begin{array}{l}\cdots \\
\cdots \\
\cdots\end{array}$ & $\begin{array}{l}\ldots \\
\ldots \\
.\end{array}$ & & \\
\hline
\end{tabular}

Seven patients described mild to moderate generalized joint improvement after an injection of $\stackrel{\mathcal{P}}{\rightarrow}$ thio-tepa, beginning 2 to 19 days after administration and persisting for 2 days to several months. In 
most, this improvement lasted no longer than 2 weeks. One patient had such improvement after a $30 \mathrm{mg}$. injection of thio-tepa on one occasion, but generalized worsening followed a subsequent injection using the same dose. Another individual had worsening of most peripheral joints after one $60 \mathrm{mg}$. injection of thio-tepa. Three individuals receiving more than one injection of thio-tepa showed systemic improvement only after one injection, but not after the others. Generalized improvement resulted after a $15 \mathrm{mg}$. injection, but not after a $45 \mathrm{mg}$. injection in one patient. Only one of the $60 \mathrm{mg}$. injections was followed by systemic improvement. Generalized improvement most frequently followed the $15 \mathrm{mg}$. dose and the longest response occurred after a $7 \cdot 5 \mathrm{mg}$. injection.
Results of synovial fluid analyses are presented in Table III. The administration of thio-tepa did not produce consistent alterations in the various parameters studied. Viscosity varied from values of $\frac{0}{\omega}$ $2 \cdot 4$ to $67 \cdot 6$, but in most instances no significant change was observed in the fluids obtained from any one individual. In some patients, the viscosity was? slightly elevated at one testing and showed no change 흠 or decreased at other times. There were others $\frac{\bar{\rho}}{\circ}$ who had a change in viscosity in one direction which $\stackrel{\varnothing}{\varnothing}$ might have been considered significant, but the reverse or contradictory results occurred in others. Two individuals (Cases 6 and 7) had what appeared. to be significant rises in viscosity after the $60 \mathrm{mg} \cdot \overrightarrow{\vec{\omega}}$ dose; another (Case 5) had no corresponding change after this same dose, but an adequate period

TABLE III

SYNOVIAL FLUID ANALYSES AFTER INTRA-ARTICULAR ADMINISTRATION ON THIO-TEPA

\begin{tabular}{|c|c|c|c|c|c|c|c|c|c|c|c|c|c|c|}
\hline \multirow[b]{2}{*}{$\begin{array}{l}\text { Case } \\
\text { No. }\end{array}$} & \multirow[b]{2}{*}{ Date } & \multicolumn{2}{|c|}{ Drug Injected } & \multirow[b]{2}{*}{$\begin{array}{l}\text { Relative } \\
\text { Viscosity }\end{array}$} & \multirow{2}{*}{$\begin{array}{c}\text { Beta- } \\
\text { Glucur- } \\
\text { onidase } \\
\text { (1) }\end{array}$} & \multirow{2}{*}{$\begin{array}{l}\text { Acid } \\
\text { Phos- } \\
\text { phatase } \\
(2)\end{array}$} & \multirow{2}{*}{$\begin{array}{c}\text { Latex } \\
\text { Test } \\
\text { (titre) }\end{array}$} & \multirow{2}{*}{$\begin{array}{c}\text { WBC } \\
\text { per } \\
\text { ml. }\end{array}$} & \multirow{2}{*}{$\begin{array}{c}\text { Poly- } \\
\text { morpho } \\
\text { Nuclears } \\
\text { (per cent) }\end{array}$} & \multicolumn{5}{|c|}{ Protein Distribution (3) } \\
\hline & & $\begin{array}{l}\text { Thio- } \\
\text { tepa } \\
\text { (mg.) }\end{array}$ & $\begin{array}{c}\text { Steroid } \\
\text { (mg.) }\end{array}$ & & & & & & & $\begin{array}{l}\text { Albu- } \\
\text { min }\end{array}$ & $\begin{array}{c}\text { Alpha } 1 \\
\text { Globulin }\end{array}$ & $\begin{array}{l}\text { Alpha } 2 \\
\text { Globulin }\end{array}$ & $\begin{array}{c}\text { Beta } \\
\text { Globulin }\end{array}$ & $\begin{array}{l}\text { Gamma } \\
\text { Globulin }\end{array}$ \\
\hline 1 & \begin{tabular}{|l|}
$6 / 11 / 63$ \\
$13 / 11 / 63$ \\
$26 / 11 / 63$ \\
$8 / 1 / 64$ \\
$5 / 2 / 64$ \\
$26 / 2 / 64$ \\
$10 / 5 / 64$ \\
$8 / 7 / 64$ \\
$15 / 7 / 64$ \\
$5 / 8 / 64$ \\
$19 / 8 / 64$ \\
\end{tabular} & $\begin{array}{l}15 \\
\overline{15} \\
30 \\
30 \\
\overline{-} \\
\overline{60} \\
\overline{-} \\
-\end{array}$ & $\begin{array}{c}25 \overline{F A c} \\
- \\
\overline{-} \\
50 \overline{F A c} \\
25 \mathrm{FAc} \\
- \\
- \\
-\end{array}$ & $\begin{array}{l}12 \cdot 5 \\
13 \cdot 2 \\
12 \cdot 5 \\
24 \cdot 7 \\
31 \cdot 1 \\
30 \cdot 7 \\
29 \cdot 5 \\
44 \cdot 9 \\
51 \cdot 0 \\
48 \cdot 7 \\
-\end{array}$ & $\begin{array}{r}5 \cdot 2 \\
6 \cdot 2 \\
8 \cdot 3 \\
8 \cdot 2 \\
13 \cdot 0 \\
5 \cdot 9 \\
10 \cdot 3 \\
6 \cdot 3 \\
10 \cdot 0 \\
12 \cdot 6 \\
-\end{array}$ & $\begin{array}{l}5 \cdot 7 \\
4 \cdot 8 \\
5 \cdot 3 \\
5 \cdot 9 \\
5 \cdot 9 \\
5 \cdot 6 \\
1 \cdot 2 \\
1 \cdot 6 \\
2 \cdot 7 \\
-\end{array}$ & \begin{tabular}{|c|}
$1: 5120$ \\
$1: 5120$ \\
$1: 5120$ \\
$1: 5120$ \\
$1: 5120$ \\
$1: 5120$ \\
$1: \overline{5}$ \\
$1: 5120$ \\
$1: 5120$ \\
$1: 5120$
\end{tabular} & $\begin{array}{c}4,300 \\
3,000 \\
2,500 \\
4,550 \\
- \\
- \\
9,050 \\
3,900 \\
-\end{array}$ & $\begin{array}{l}54 \\
43 \\
51 \\
44 \\
- \\
\overline{-} \\
\overline{52} \\
72 \\
-\end{array}$ & $\begin{array}{l}63 \cdot 6 \\
47 \cdot 5 \\
56 \cdot 9 \\
68 \cdot 5 \\
6 \overline{63} \cdot 0 \\
70 \cdot 0 \\
73 \cdot 0 \\
68 \cdot 0 \\
66 \cdot 4 \\
77 \cdot 7\end{array}$ & $\begin{array}{l}5 \cdot 3 \\
8 \cdot 0 \\
6 \cdot 0 \\
3 \cdot 8 \\
4 \cdot 8 \\
3 \cdot 0 \\
3 \cdot 6 \\
4 \cdot 4 \\
4 \cdot 4 \\
3 \cdot 3\end{array}$ & $\begin{array}{r}7 \cdot 5 \\
11 \cdot 0 \\
7 \cdot 1 \\
6 \cdot 5 \\
\overline{6 \cdot 0} \\
5 \cdot 4 \\
5 \cdot 8 \\
5 \cdot 7 \\
6 \cdot 3 \\
5 \cdot 3\end{array}$ & $\begin{array}{r}9 \cdot 8 \\
12 \cdot 3 \\
14 \cdot 4 \\
8 \cdot 5 \\
12 \cdot 2 \\
9 \cdot 4 \\
7 \cdot 5 \\
10 \cdot 1 \\
10 \cdot 5 \\
9 \cdot 6\end{array}$ & $\begin{array}{c}13 \cdot 8 \\
21 \cdot 2 \\
15 \cdot 6 \\
12 \cdot 7 \\
14 \cdot 0 \\
11 \cdot 0 \\
10 \cdot \frac{0}{10} \\
11 \cdot \frac{2}{2} \\
11 \cdot 7 \\
9 \cdot 1\end{array}$ \\
\hline 2 & $\begin{array}{l}28 / 10 / 63 \\
29 / 2 / 64 \\
6 / 3 / 64\end{array}$ & $\begin{array}{r}7 \cdot 5 \\
30 \\
-\end{array}$ & E & $\begin{array}{l}32 \cdot 6 \\
18 \cdot 8 \\
21 \cdot 6\end{array}$ & $\frac{8 \cdot 5}{12 \cdot 2}$ & $\begin{array}{l}\frac{6 \cdot 8}{7 \cdot 4} \\
\cdot\end{array}$ & $\begin{array}{l}1: 2560 \\
1: \overline{2560}\end{array}$ & $\begin{array}{r}5,650 \\
7,200 \\
11,700\end{array}$ & $\overline{53}$ & $\begin{array}{l}51 \cdot 5 \\
5 \overline{3} \cdot 8\end{array}$ & $\begin{array}{l}8 \cdot 0 \\
\overline{7 \cdot 2}\end{array}$ & $\begin{array}{l}9 \cdot 8 \\
\overline{9 \cdot 0}\end{array}$ & $\frac{10 \cdot 2}{12 \cdot 0}$ & $\begin{array}{c}20 \cdot 5 \\
18 \cdot 0\end{array}$ \\
\hline 3 & $\begin{array}{l}7 / 1 / 64 \\
18 / 2 / 64 \\
25 / 2 / 64\end{array}$ & $\overline{15}$ & $\begin{array}{c}30 \mathrm{MP} \\
- \\
-\end{array}$ & $\begin{array}{l}17 \cdot 5 \\
18 \cdot 2 \\
18 \cdot 9\end{array}$ & $\begin{array}{l}5 \cdot 7 \\
4 \cdot 2 \\
3 \cdot 3\end{array}$ & $\begin{array}{l}7 \cdot 0 \\
6 \cdot 7 \\
7 \cdot 4\end{array}$ & $\begin{array}{l}\text { Negative } \\
\text { Negative } \\
\text { Negative }\end{array}$ & $\begin{array}{l}5,950 \\
5,200 \\
8,000\end{array}$ & E & $\begin{array}{l}69 \cdot 0 \\
69 \cdot 5 \\
61 \cdot 0\end{array}$ & $\begin{array}{l}4 \cdot 0 \\
5 \cdot 0 \\
6 \cdot 0\end{array}$ & $\begin{array}{l}8 \cdot 5 \\
7 \cdot 0 \\
7 \cdot 3\end{array}$ & $\begin{array}{r}7 \cdot 5 \\
9 \cdot 0 \\
11 \cdot 4\end{array}$ & $\begin{array}{l}11 \cdot 0 \\
11 \cdot 5 \\
14 \cdot 3\end{array}$ \\
\hline 4 & $\begin{array}{l}24 / 10 / 65 \\
31 / 10 / 65\end{array}$ & $\begin{array}{l}7 \cdot 5 \\
15\end{array}$ & - & $\begin{array}{r}10 \cdot 1 \\
4 \cdot 7\end{array}$ & $\begin{array}{l}21 \cdot 0 \\
21 \cdot 9\end{array}$ & $\overline{7 \cdot 1}$ & $\begin{array}{l}1: 5120 \\
1: 5120\end{array}$ & $\begin{array}{c}4,350 \\
-\end{array}$ & - & $\begin{array}{l}38 \cdot 0 \\
43 \cdot 5\end{array}$ & $\begin{array}{l}7 \cdot 0 \\
8 \cdot 0\end{array}$ & $\begin{array}{l}14 \cdot 0 \\
10 \cdot 5\end{array}$ & $\begin{array}{l}13 \cdot 5 \\
13 \cdot 5\end{array}$ & $\begin{array}{l}24 \cdot 5 \\
24 \cdot 5\end{array}$ \\
\hline 5 & $\begin{array}{l}7 / 7 / 64 \\
8 / 7 / 64 \\
9 / 7 / 64 \\
13 / 7 / 64 \\
18 / 7 / 64 \\
20 / 7 / 64\end{array}$ & $\begin{array}{l}\overline{60} \\
- \\
-\end{array}$ & 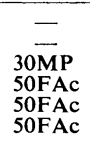 & $\begin{array}{l}2 \cdot 4 \\
3 \cdot 9 \\
2 \cdot 4 \\
2 \cdot 8 \\
2 \cdot 5 \\
4 \cdot 3\end{array}$ & $\begin{array}{l}17 \cdot 0 \\
13 \cdot 1 \\
12 \cdot 1 \\
17 \cdot 1 \\
16.9 \\
13 \cdot 3\end{array}$ & $\begin{array}{l}1.9 \\
0.9 \\
1.5 \\
1.6 \\
3.2 \\
1.7\end{array}$ & $\begin{array}{l}- \\
\text { Negative } \\
\text { Negative } \\
\text { Negative } \\
\text { Negative } \\
\text { Negative }\end{array}$ & $\begin{array}{c}13, \overline{950} \\
6,600 \\
12,430 \\
- \\
-\end{array}$ & $\begin{array}{l}-\overline{69} \\
70 \\
78 \\
- \\
-\end{array}$ & $\begin{array}{l}60 \cdot 3 \\
61 \cdot 0 \\
58 \cdot 2 \\
58 \cdot 3 \\
56 \cdot 0 \\
56 \cdot 8\end{array}$ & $\begin{array}{l}5 \cdot 6 \\
5 \cdot 4 \\
4 \cdot 7 \\
5 \cdot 4 \\
4 \cdot 6 \\
5 \cdot 7\end{array}$ & $\begin{array}{l}7 \cdot 8 \\
7 \cdot 7 \\
8 \cdot 8 \\
8 \cdot 5 \\
9 \cdot 9 \\
8 \cdot 5\end{array}$ & $\begin{array}{l}11 \cdot 1 \\
11 \cdot 3 \\
12 \cdot 0 \\
11 \cdot 5 \\
15 \cdot 6 \\
12 \cdot 7\end{array}$ & $\begin{array}{l}15 \cdot 1 \\
14 \cdot 5 \\
16 \cdot 1 \\
16 \cdot 2 \\
14 \cdot 6 \\
16 \cdot 2\end{array}$ \\
\hline 6 & $\begin{array}{l}1 / 7 / 64 \\
22 / 7 / 64 \\
29 / 7 / 64 \\
5 / 8 / 64 \\
12 / 8 / 64 \\
\end{array}$ & $\begin{array}{l}\overline{60} \\
- \\
-\end{array}$ & $\begin{array}{l}E \\
E\end{array}$ & $\begin{array}{l}15 \cdot 6 \\
16 \cdot 6 \\
32 \cdot 8 \\
31 \cdot 6 \\
67 \cdot 6\end{array}$ & $\begin{array}{l}3 \cdot 3 \\
3 \cdot 5 \\
4 \cdot 8 \\
6 \cdot 0\end{array}$ & $\begin{array}{l}0.4 \\
0.3 \\
0.6 \\
1.6\end{array}$ & $\begin{array}{l}\text { Negative } \\
\text { Negative } \\
\text { Negative } \\
\text { Negative } \\
\text { Negative }\end{array}$ & $\begin{array}{c}7,850 \\
8,150 \\
2,100 \\
- \\
-\end{array}$ & $\begin{array}{l}36 \\
38 \\
48 \\
- \\
\end{array}$ & $\begin{array}{l}- \\
- \\
65 \cdot 1 \\
70 \cdot 8\end{array}$ & $\begin{array}{l}\overline{-} \\
\overline{4} \cdot 3 \\
3 \cdot 6\end{array}$ & $\begin{array}{l}\overline{-} \\
\overline{7} \\
\overline{7} \cdot 1 \\
6 \cdot 3\end{array}$ & $\begin{array}{l}\overline{-} \\
\bar{z} \\
8 \cdot 4 \\
8 \cdot 2\end{array}$ & $\begin{array}{l}\bar{Z} \\
\overline{-} \\
15 \cdot 0 \\
10 \cdot 9\end{array}$ \\
\hline 7 & $\begin{array}{l}8 / 7 / 64 \\
22 / 7 / 64 \\
29 / 7 / 64\end{array}$ & $\frac{60}{-}$ & E & $\begin{array}{r}8 \cdot 3 \\
34 \cdot 2 \\
19 \cdot 9\end{array}$ & $\begin{array}{l}12 \cdot 4 \\
21 \cdot 8 \\
12 \cdot 8\end{array}$ & $\begin{array}{l}5 \cdot 7 \\
4 \cdot 0 \\
2 \cdot 8\end{array}$ & $\begin{array}{l}1: 5120 \\
1: 5120 \\
1: 5120\end{array}$ & $\begin{array}{l}25,500 \\
29,500 \\
24,450\end{array}$ & $\begin{array}{l}78 \\
90 \\
76\end{array}$ & E & E & - & - & - \\
\hline 8 & $\begin{array}{l}8 / 7 / 64 \\
10 / 7 / 64 \\
15 / 7 / 64 \\
18 / 7 / 64\end{array}$ & $\begin{array}{l}60 \\
-\end{array}$ & $\begin{array}{l}- \\
\text { - }\end{array}$ & E & $\begin{array}{l}11 \cdot 0 \\
13 \cdot 0 \\
11 \cdot 2 \\
12 \cdot 4\end{array}$ & $\begin{array}{l}4 \cdot 1 \\
3 \cdot 4 \\
3 \cdot 4\end{array}$ & $\begin{array}{l}1: 5120 \\
1: 5120 \\
1: 5120\end{array}$ & $\begin{array}{r}10,600 \\
\bar{Z} \\
34,000\end{array}$ & $\frac{88}{\overline{90}}$ & E & E & E & E & E \\
\hline
\end{tabular}

NOTES

(1) $\mu \mathrm{g}$. phenolphthalein liberated per hour by $1 \mathrm{ml}$. synovial fluid.

(2) King-Armstrong units.

(3) Determined by paper electrophoresis.

FAc $=$ Hydrocortisone acetate

MP = 6-methyl prednisolone. 
of time may not have elapsed before further viscosity determinations were performed on the fluid in this case. $\beta$-glucuronidase values ranged from $3 \cdot 3$ to 21.0 units $/ \mathrm{ml}$., but again no consistent change was noted. For the most part alterations were minimal. Acid phosphatase values also showed no consistent variations. The latex test revealed no changes after thio-tepa administration; three patients had negative results throughout. The leucocyte counts in the synovial fluid did not show a definitive decrease or increase, although both occurred at different times and could not be correlated with the medication. Those changes that occurred in the protein distribution as determined by paper electrophoresis were also inconsistent, and varied in the same individual and from one patient to the next.

Haematological alterations were probably attributable to thio-tepa administration in some instances while they were possibly coincidental in others. The erythrocyte sedimentation rate was decreased in six patients; this was noted 2 to 3 weeks after thio-tepa administration and did not correlate significantly with those individuals who described systemic improvement. The white blood cell count was lowered slightly in five patients, and the haemoglobin in one, but these findings were of brief duration and resulted in no serious complications. Neither leucopenia nor agranulocytosis developed. Platelets were depressed in one patient after an injection of $7.5 \mathrm{mg}$. thio-tepa; this individual also developed petechiae. The platelets returned to normal about 1 month after thio-tepa was stopped. The serum latex test was not significantly altered.

Local reactions of pain occurred after nine injections of thio-tepa when doses of $7 \cdot 5$ to $30 \mathrm{mg}$. were utilized, but this toxicity was very similar in both the control and thio-tepa injected knees. After administration of the $60 \mathrm{mg}$. dose to six patients, local pain was described in five. In four, this pain was immediate and lasted 5 to 15 minutes, being very severe $(4+)$ in one. A fifth patient developed marked pain and swelling $(4+)$ beginning about 5 hours after the injection. These latter reactions to the $60 \mathrm{mg}$. dose were more severe than those seen after control injections or after the administration of smaller doses of thio-tepa.

Nausea and vomiting developed in three of six patients who received the $60 \mathrm{mg}$. dose and after the $45 \mathrm{mg}$ dose in another patient. This did not occur after the administration of smaller doses. The nausea persisted for several days in most instances, and the emesis about 1 day. Darvon* was administered simultaneously to one of these patients

* Dextro propoxyphene hydrochloride and could have contributed to the gastrointestinal toxicity.

\section{Discussion}

Alkylating agents have been used extensively in the treatment of certain malignancies on the basis of their inhibitory action on cell growth. These drugs have also been administered in human organ transplant experiments, and beneficial results have been ascribed in part to their depressant effect on the immune response. Therefore, the use of the alkylating agent, thio-tepa, in the treatment of rheumatoid arthritis has sound theoretical basis because of its potential anti-inflammatory action and its antiimmune activity.

Thio-tepa was injected intra-articularly into knee joints of patients with rheumatoid arthritis in this study. Significant beneficial responses did not ensue. Both immediate and possible delayed effects of thio-tepa was evaluated and in neither period was improvement of a consistent nature obtained. Potential delayed responses were studied because alkylating agents may require more time before any effect can be ascertained. Reasons for the discrepancy between the poor results obtained in this investigation as compared to improvement reportec in other studies may be multiple. No complicating additional medications were injected into the joints of these patients as contrasted to the simultaneous injection of a local anaesthetic or steroid in combination with thio-tepa in other studies. In addition, controls generally were lacking in other reports. The dose of thio-tepa seemed adequate in this investigation, as dosages up to $60 \mathrm{mg}$. were injected without significant benefit. This dose compared favourably with that administered systemically for therapy of neoplasia. Administering larger amounts of thio-tepa did not seem advisable because of its high potential toxicity.

If one assumes that absorption through the synovial membrane results in sufficient amounts of thio-tepa entering into the circulation, generalized improvement as well as localized improvement might be anticipated. This would be particularly applicable to the larger $60 \mathrm{mg}$. doses that were administered. Such was not the case, however. Although some patients did describe systemic benefit after an injection, it did not necessarily follow subsequent injections. This improvement was also not related to the dosage, since $60 \mathrm{mg}$. injections gave fewer generalized responses than the smaller doses. Those few instances of reported generalized improvement would have to be considered as coincidental and not related to the medication.

Synovial fluid analyses for relative viscosity, titre 
of rheumatoid factor, leucocyte count, serum protein distribution, and beta-glucuronidase and acid phosphatase activities were performed before and after thio-tepa administration. Elevated leucocyte counts and increased levels of beta-glucuronidase (Jacox and Feldmahn, 1955) and acid phosphatase (Smith and Hamerman, 1962) are usually found in rheumatoid synovial fluid. Since leucocytes contain lysosomes that liberate the enzymes beta-glucuronidase and acid phosphatase, changes in the leucocyte count might be expected to cause proportional changes in these enzyme levels (Smith and Hamerman, 1962). Testing these factors might, therefore, give important information. The amount of rheumatoid factor and the quantity of the various protein fractions could be indicators of an effect of thio-tepa on the immune mechanism. The latex test and paper electrophoresis were therefore performed on the synovial fluid and the former on the serum also. Viscosity of synovial fluid is known to decrease with increasing inflammation. If thiotepa were to be beneficial, the viscosity which is decreased in rheumatoid arthritis might be expected to rise. Analysis of these parameters in the synovial fluid revealed no significant changes produced by thio-tepa. In general, the negative results produced clinically by thio-tepa correlated with the lack of significant change in the synovial fluid constituents tested. The possibility exists that larger doses of thio-tepa might cause a rise in viscosity since two fluids did have a higher viscosity after $60 \mathrm{mg}$. injections, but the significance of this is difficult to assess because the information is limited. Also, the enzyme determinations may not have given true values because leucocytes were removed by centrifugation before the fluid was ultrasonified. Despite this, variations in the enzyme levels so determined would have been expected if thio-tepa had an effect.

Toxic manifestations due to the thio-tepa included local reactions, systemic gastrointestinal symptoms and haematological alterations. Only minor pain developed in injected joints when smaller doses were used, but severe reactions occurred in two cases when the larger $60 \mathrm{mg}$. dose was administered. This larger dose also caused nausea and vomiting, whereas smaller amounts of thio-tepa did not. The lowered platelet count that appeared in one patient after the injection of $7.5 \mathrm{mg}$. did not occur after other larger injections. These toxic reactions show the necessity for special care in evaluating the effect of these agents in the treatment of the rheumatic diseases.

Although thio-tepa did not prove beneficial as used in this study, other agents of similar nature may play a role in the therapy of rheumatoid arthritis or closely related connective tissue diseases. 꿍 The importance of balancing the advantages of such $\stackrel{\mathbb{D}}{=}$ therapy against the disadvantages cannot be over- 3 emphasized because toxic reactions are frequent and $\frac{\sigma}{\omega}$. potentially serious.

\section{Summary}

Thio-tepa injected intra-articularly in doses of $\frac{\overline{\bar{c}}}{\overline{5}}$ 7.5 to $60 \mathrm{mg}$. in nineteen patients with rheumatoid $\stackrel{\Phi}{\Omega}$ arthritis resulted in no significant improvement. Synovial fluid analyses for viscosity, latex test, leucocyte count, protein distribution as determined. by paper electrophoresis, and acid phosphatase and $\vec{\omega}$ beta-glucuronidase activities did not reveal any consistent alterations attributable to thio-tepa. $\frac{\cong}{2}$ Haematological changes manifested by a decrease in platelets in one patient and by lowered, but not leucopenic, white blood cell counts in five patients. indicated that potentially serious complications $\vec{\infty}$ could ensue with such therapy.

\section{REFERENCES}

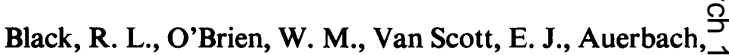
R., Eisen, A. Z., and Bunim, J. J. (1964). J. Amer. med. Ass., 189, 743.

Cohen, A., Rose, I., and Cooper, E. (1953). Ibid., 15, 402.

Dorner, R. W., Gantner, G. E., Jr., Uddin, J., ậd Zuckner, J. (1965). Arthr. and Rheum., 8, 368.

Flatt, A. E. (1962). Rheumatism, 18, 70.

Gross, D. (1963). "Intra-articular Treatment of Rheumatoid Arthritis with Nitrogen Mustard $\overrightarrow{\vec{B}}$ (Thio-tepa)." Fifth European Congress of Rheumatology, Stockholm, August, 1963.

Jacox, R. F., and Feldmahn, A. (1955). J. clin. Invest. 34, 263.

Jiménez Díaz, C. (1951). Ann. rheum. Dis., 10, 144.

—, Lopéz García, E., Merchante, A., and Perianes, J.등 (1951). J. Amer. med. Ass., 147, 1418.

Kalliomäki, J. L., Saarimaa, H. A., and Toivanen, P. (1964). Ann. rheum. Dis., 23, 78.

Lee, S. L., Meiselas, L. E., Zingale, S. B., and Richman, S. M. (1961). Arthr. and Rheum., 4, 56.

O'Brien, W. M., Van Scott, E. J., Black, R. L., Eisen, A. Z., and Bunim, J. J. (1962). Ibid., 5, 312.

Pace, N., Kantor, T., and McEwen, C. (1964). Ibid., 7, 337.

Phillips, A. M., Phillips, R. W., and Caraway, W. T.N (1952). R.I. med.J., 35, 610.

Powell, M. E. A., and Smith, M. J. H. (1954). J. clin. Path., 7, 245.

Sandson, J., and Hamerman, D. (1958). Proc. Soc. expœ Biol. (N.Y.), 98, 564.

Schachman, H. K. (1957). In "Methods in Enzymology", ed. S. P. Colowick and N. O. Kaplan, vol. 4, pp. 32-103. Academic Press, New York. 
Scherbel, A. L. (1957). Cleveland Clin. Quart., 24, 71.

-, Mackenzie, A. H., and Atdjian, M. (1963). "Experience with Alkylating Drugs for the Suppression of the Inflammatory Reaction of Connective Tissue Diseases". Fifth European Congress of Rheumatology, Stockholm, August, 1963.

- Schuchter, S. L., and Weyman, S. J. (1957). Cleveland Clin. Quart., 24, 78.

Shutkin, N. M. (1951). J. Bone Jt Surg., 33-A, 265.

Singer, J. M., and Plotz, C. M. (1956). Amer. J. Med., 21, 888.

Smith, C., and Hamerman, D. (1962). Arthr. and Rheum., 5, 411.

Steinbrocker, O., Traeger, C. H., and Batterman, R. C. (1949). J. Amer. med. Ass., 140, 659.

Evaluation critique de l'efficacité de

l'administration intra-articulaire d'un agent alcoylant, Thio-tepa, dans l'arthrite rhumatismale

\section{RÉSUMÉ}

Thio-tepa par voie intra-articulaire aux doses de 7,5 à $60 \mathrm{mg}$. administré à 19 malades atteints d'arthrite rhumatismale ne produisit pas d'amélioration significative. La détermination de la viscosité du liquide synovial, le test au latex, la numération leucocytaire, l'analyse des protéines par l'électrophorèse sur papier, la phosphatase acide et la beta-glucouronidase ne révélèrent aucune altération attribuable au Thio-tepa. Des altérations hématologiques, telles qu'une baisse thrombocytaire chez un malade et un chiffre leucocytaire bas (sans vraie leucopénie) chez cinq malades indiqua que cette thérapie peut provoquer des complications potentiellement sérieuses.

\section{Valoración crítica de la eficacidad de la administración intra-articular de un agente alquilante, Thio-tepa, en la artritis reumatoide}

\section{Sumario}

Thio-tepa administrado por vía intra-articular en dosis de 7,5 a $60 \mathrm{mg}$. a 19 enfermos con artritis reumatoide no produjo mejoría significativa. La determinación de la viscosidad del líquido sinovial, el test de latex, la fórmula leucocitaria, el análisis de proteinas por electroforesis sobre papel, la fosfatasa ácida y la beta-glucouronidasa no revelaron alteraciones concretas atribuibles a Thiotepa. Alteraciones hematológicas, como la baja de las plaquetas en un enfermo y cifras leucocitarias bajas (sin verdadera leucopenia) en cinco enfermos indicaron que esta terapia puede llevar a complicaciones potencialmente serias. 